\title{
Apontamentos para uma sociologia da valentia
}

\section{ELIÉZER GARDOSO DE OLIUEIRA*}

\section{Resumo}

O artigo objetiva a construção de uma tipologia da valentia a partir da sociologia compreensiva de Weber, Simmel e Elias. A valentia é considerada como uma escolha valorativa de indivíduos inclinados a levarem uma vida de aventura e convictos da legitimidade de um estilo de vida baseado na proximidade com a violência, com a morte e com o risco. Mesmo com o advento da modernidade, quando emergiu o "processo civilizador", responsável por refrear os instintos violentos, a valentia, restringida na vida cotidiana, mantém-se atuante como um valor social legítimo.

Palavras-Chave: Sociologia da valentia. Violência. Esferas valorativas.

\footnotetext{
* Universidade Estadual de Goiás (Brasil)
} 


\section{Notes for a sociology of bravery}

\section{Abstract}

This article aims to construct a typology of valor based on the comprehensive sociology of Weber, Simmel, and Elias. Valor is considered an evaluative choice by individuals inclined to lead a life of adventure and convinced of the legitimacy of a lifestyle based on the proximity to violence, death, and risk. Even with the advent of modernity, and the emergence of the "civilizing process" - responsible for curbing violent instincts -, bravery, restricted in everyday life, remains active as a legitimate social value.

Keywords: Sociology of bravery. Violence. Evaluative spheres.

\section{Introdução}

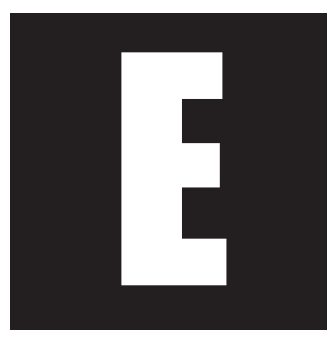

m novembro de 2005, o deputado baiano Antônio Carlos Magalhães Neto, seguindo o precedente aberto pelo senador Arthur Virgílio, ameaçou o presidente Lula com uma surra: "O presidente da República, ou qualquer um dos seus que tiver coragem de se meter na minha frente, assim como disse o senador Arthur Virgílio, tomará uma surra. Não me intimido. Tenho coragem e vou até o fim. Não mexam com os meus nem comigo, porque estou pronto para me defender". Essa declaração, logicamente, ganhou grande repercussão e não foi muito bem aceita no meio político. A prova disso é que, nas eleições municipais de 2012, o agora ex-presidente Lula explorou politicamente a ameaça do então candidato a prefeito de Salvador Magalhães Neto: "Se esse cidadão teve coragem de dizer que queria bater no presidente da República, adivinha o que ele vai fazer com camelô aqui em Salvador ${ }^{1 "}$. O candidato sentiu

\footnotetext{
${ }^{1}$ Lula ataca ACM Neto em palanque da campanha petista em Salvador. 15/09/2012. In. http:// www1.folha.uol.com.br/fsp/poder/66337-lula-ataca-acm-neto-em-palanque-da-campanha-petista-em-salvador.shtml. Acessado em: 24 maio 2013.
} 
o golpe e pediu desculpas por sua "imaturidade": "Reagi realmente de uma forma indevida. Eu não tinha a experiência que tenho hoje. Estava começando a minha carreira ${ }^{2 \prime}$.

Esses episódios demonstram o quanto os comportamentos associados à disposição a usar a violência para resolver conflitos cotidianos estão presentes na sociedade brasileira, inclusive entre os membros da elite política nacional. Porém, as críticas suscitadas demonstram também que essa "retórica da valentia" está sendo cada vez mais questionada e associada ao resquício de anacrônicas práticas autoritárias e truculentas coronelísticas. Nessa perspectiva, é preciso ter em mente que tais manifestações de virilidade são, muitas vezes, mais arroubos discursivos do que um indicativo concreto de um desejo de se envolver em ações violentas. De qualquer modo, o que é popularmente denominado de "valentia" ainda se configura como um importante valor social, atuante na política, nos esportes, nas brincadeiras infantis, nas produções culturais, nos discursos e práticas cotidianas. Portanto, estudá-la permite refletir sobre um componente cultural da violência, surpreendentemente pouco abordado pelos cientistas sociais.

Para uma fundamentação teórica mais consistente desses discursos e práticas associadas a pessoas tidas como "valentes", é pertinente não as considerar como portadoras de uma qualidade psicológica inata, que as distinguiria dos demais seres humanos. Seja considerada como uma qualidade positiva ou negativa, a "valentia" é uma atribuição social; ninguém, por si só, nasce valente ou covarde, mas vai construindo em torno de si uma identidade que será interpretada nesses dois polos pelos integrantes de seu grupo social.

Sendo assim, ela é também histórica, já que cada época vai ter atributos específicos para considerar uma pessoa ou uma ação como valente

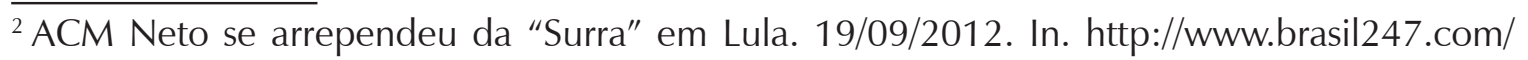
pt/247/bahia247/80770/. Acessado em: 24 maio 2013. 
ou covarde. Nesse sentido, o papel desempenhado pelos indivíduos valentes em Esparta não foi o mesmo na rival Atenas. Ser valente na Roma Antiga era diferente de ser valente na Judeia: Horácio Cocles e Sansão são heróis de estirpe diferente, uma vez que a coragem do primeiro era eminentemente profana, enquanto a do segundo era um dom divino para ajudar a comunidade.

Além disso, as práticas e discursos associados à valentia dependem da inserção do indivíduo em uma determinada instituição. Algumas atividades estão intimamente relacionadas a uma representação da valentia, como é o caso dos lutadores profissionais, dos soldados e policiais, dos pistoleiros profissionais ou membros de torcidas organizadas de futebol. Em todos esses casos, há uma proximidade com a violência. Contudo, uma pessoa comum poderá ser reconhecida em seu meio como valente pela habilidade demonstrada em uma briga de trânsito ou num impulso para enfrentar um assaltante.

Portanto, diante da complexidade e da abrangência do que é ou foi considerado "valentia", é necessário avançar para uma definição sociológica mais rigorosa desse importante atributo social. Nesse sentido, este artigo pretende analisar sociologicamente a valentia, valendo-se de autores clássicos como Weber, Simmel e Norbert Elias, dentre outros. Ele é dividido em duas partes: na primeira, analisa-se a presença ambígua da valentia na sociedade moderna, na qual o Estado procura restringi-la e domesticá-la para reforçar a pacificação social; na segunda, procurou-se caracterizar a esfera da valentia, pautando-se na sociologia compreensiva alemã. Em termos metodológicos, o artigo vale-se dos exemplos empíricos retirados da literatura histórica e dos registros digitais do Exército Norte-Americano referentes aos agraciados pela Medal of Honor. 


\section{A valentia numa sociedade pacificada}

A relação da sociedade contemporânea com a valentia é marcada por uma curiosa ambiguidade: ao mesmo tempo em que é desvalorizada como uma sobrevivência anacrônica de uma época de incivilizada brutalidade, a valentia permanece sedutoramente presente no cotidiano, vislumbrada por meio do prestígio dos lutadores profissionais e dos heróis de cinema, revistas em quadrinhos e videogames. No entanto, é inegável que a valentia, com a modernidade, foi perdendo espaço na sociedade, diminuindo os seus efeitos nas relações cotidianas e refugiando-se num ambiente em que é restringida por regras - como o dos lutadores ou soldados profissionais - ou num ambiente do mundo ilusório da ficção - como é o caso dos heróis do cinema. O elemento-chave para a inibição da valentia foi a ação do Estado, que concentrou a violência no seu aparato repressivo e inibiu a sua manifestação gratuita e desregulada no âmbito das relações privadas.

A manifestação privada da valentia foi gradativamente restringida e deslegitimada pelo Estado, que passou a proibir duelos, a restringir o uso de armas, a criminalizar justiceiros e a agressão física privada. Para se compreender como a valentia foi perdendo espaço na sociedade moderna, é pertinente a análise de Norbert Elias sobre o processo civilizador. A sua eclosão foi consequência da monopolização da violência pelos estados nacionais e da complexidade da interação dos indivíduos com a diversificação da divisão de trabalho.

Esses fatores tomaram corpo pela primeira vez nas cortes dos monarcas absolutistas europeus, quando a nobreza guerreira medieval foi pacificada e aprendeu a calcular suas atitudes para obter privilégios do rei e manter sua supremacia diante da burguesia em ascensão. Das cortes absolutistas, esse comportamento foi apropriado pela burguesia, tornando-se a maneira típica de os ocidentais se comportarem. A pacificação da 
conduta tornou-se um padrão moral dos "civilizados" e os atos associados à violência passaram a ser regulados e repudiados. Segundo Elias,

Em sociedades desse tipo atingiu-se um ponto em que os dirigentes permitem o uso da violência apenas a grupos específicos controlados por eles. Em muitos casos somente eles - a polícia e as forças armadas - são autorizadas a portar armas sem risco de punição e, mesmo, a usá-las em certas situações. (Elias, 2001a, p. 56).

Essa situação é bem diferente daquela existente antes da emergência do processo civilizador, quando os nobres feudais da época possuíam uma ampla liberdade de exteriorizar a sua valentia:

O guerreiro da Idade Média não amava só a guerra, vivia dela. Passava a juventude preparando-se para isso. Ao chegar à idade apropriada, era armado cavaleiro e fazia a guerra enquanto forças the permitiam até a velhice. Sua vida não tinha outra função (Elias, 1994, p. 193).

A partir do século XI, a aristocracia francesa perdeu o seu caráter guerreiro e tornou-se uma nobreza cortesã. O processo culmina com o Absolutismo, quando monarcas vigorosos, como Luís XIV, literalmente colocam os nobres para dançar nos vistosos salões de Versalhes. Na corte real e nas cidades, o guerreiro convivia com outros guerreiros e gradativamente aprendeu a controlar seus instintos e a conviver pacificamente. A intensificação das relações comerciais e o controle político e fiscal das terras pelo rei também influenciaram a domesticação dos guerreiros. Para Norbert Elias (1993, p. 246), "moldando-se pelo entrelaçamento de atividades pacíficas - como a produção de bens, o comércio e o transporte - a homens pacificados, aparece uma natureza igualmente apaziguada, que eles podem enxergar de uma nova maneira".

No entanto, para Elias, a pacificação social não aconteceu no mesmo ritmo e intensidade nos diferentes estados europeus. O caso francês foi paradigmático, mas difere do inglês e do alemão. 
Na corte francesa, a pacificação foi sublimada nas regras de etiqueta que legitimavam a competição da nobreza por prestígio (Elias, 2001b). Na Inglaterra, a sublimação se deu nos desportos, que permitiram à aristocracia competir em meio a regras cada vez mais sistematizadas. Isso porque o desenvolvimento social inglês não foi pautado na luta entre aristocracia e burguesia, mas na disputa entre dois segmentos aristocráticos: os whigs e os tories. Logo, as duas facções, após séculos de desavenças, "unidas por um código de sensibilidade e de conduta 'próprio de cavalheiros' aprenderam a confiar o suficiente nos outros, determinando o aparecimento de um tipo de confronto não violento no Parlamento" (Elias; Dunning, 1992, p. 56). Com isso, a aristocracia aprendeu a resolver os conflitos por meio do debate parlamentar e adotou também, nos seus divertimentos desportivos, regras formalizadas e a arbitragem para garantir a lisura das disputas.

O pioneiro dentre os desportos modernos foi a caça à raposa, no final do século XVIII. Nesse jogo, os competidores levavam a sua matilha de cães para perseguir e matar a raposa. Trata-se, nas palavras de Elias (Elias; Dunning, 1992, p. 245), "da caça transformada em desporto", em que desapareceu "o prazer de comer, enquanto motivo para caçar", já que a raposa não servia como alimento, e atenuou-se "o prazer de matar", já que quem matava a raposa era o cão, e não o homem. Outro desporto em que se evidencia melhor a pacificação e a formalização foi a transformação do futebol medieval nos equivalentes futebol e rúgbi modernos. De uma disputa anárquica que envolvia mais de dois mil adversários em busca de uma bola, sem regras formalizadas nem árbitro, em que eram comuns "ossos quebrados e narizes ensanguentados", evoluiu para um confronto de habilidades físicas que procurava inibir a violência (Elias; Dunning, 1992, p. 260), ou seja, o desporto possibilita a "experiência de excitação total de uma luta sem os seus perigos e riscos" (idem, p.83).

Já a configuração do processo civilizador na Alemanha foi distinta do que ocorreu na França e na Inglaterra. Na Alemanha, a aristocracia não 
enfrentou uma burguesia resoluta (como na França) e não se digladiou numa guerra civil (como na Inglaterra); pelo contrário, ela liderou o processo de unificação, que foi efetivado por meio "de uma guerra vitoriosa" (a de 1871), o que "proporcionou ainda maior prestígio aos aristocráticos oficiais e aos militares" (Elias, 1997, p. 61). Por causa disso, um ethos militar que valorizava as proezas militares impregnou o caráter nacional alemão, o que explicaria, em parte, o seu protagonismo nas duas guerras mundiais. A burguesia incorporou esse ethos, adotando um gosto extravagante por uniformes militares e, o mais grave, a crença de que a guerra é um instrumento eficaz na resolução dos conflitos internacionais.

O significado desse ethos aristocrático se evidencia na centralidade que o ritual do duelo teve nas altas classes alemãs, de meados do século XIX e início do XX, período em que foi duramente reprimido na França e Inglaterra. Para a aristocracia alemã, o duelo reafirmava o poder de classe, já que, entre os seus membros, os conflitos eram resolvidos diretamente pela força e não pela mediação dos instrumentos coercitivos do Estado. "O código de honra dos aristocratas tinha prioridade sobre as leis do Estado" (Elias, 1997, p. 72). A força evocativa do duelo disseminou-se para os setores médios alemães, notadamente entre as confrarias estudantis, onde a competição de esgrima era um ritual obrigatório. Embora, no caso dos estudantes, houvesse regras para evitar danos físicos letais, tratava-se de um espetáculo violento, em que "podia-se com um único talho, dividir o nariz e os lábios do outro [...]; orelhas cortadas podiam ficar pendentes e o sangue fluir em borbotões pelas veias das têmporas" (Elias, 1997, p. 105).

A especificidade do processo civilizador na França, Inglaterra e Alemanha mostra uma tolerância diferenciada com a demonstração de força e coragem. Na França, o espaço era restrito e a luta se desenrolava no plano simbólico, tendo como palco as observâncias das regras de etiquetas nos salões da corte; na Inglaterra, o desporto possibilitava a demonstração 
legítima da valentia e excitação com a luta, em esportes como a caça à raposa, o rúgbi e o futebol; na Alemanha, de modo bem menos sutil, o duelo valorizava pessoas que "se distinguem não só por seu vigor físico ou habilidade, mas também pelo prazer que sentem em esmagar outras pessoas com armas ou com palavras" (Elias, 1997, p. 74). Os três casos demonstram que o processo civilizador restringe, mas não elimina a possibilidade da demonstração da valentia. No decorrer do século XX, a sutileza do modelo francês restringiu-se aos altos círculos sociais burgueses e aos nichos aristocráticos, enquanto o rústico modelo alemão sucumbiu junto com o nazismo. Já o modelo inglês difundiu-se pelo mundo por meio da excitação dos esportes de massa, principalmente o futebol. Isso significa que a demonstração de valentia foi controlada por regras criadas pelas federações desportivas, no caso dos atletas, ou pelo Estado, no caso dos policiais e soldados.

Complementando a análise de Elias, o sociólogo Charles Tilly resume a história política da pacificação europeia, demonstrando a mudança da representação do chefe político em quatro quadros:

19) O rei usa armadura e carrega uma espada, recrutando e comandando o seu próprio exército e marinha.

$2^{\circ}$ ) $\mathrm{O}$ rei veste um traje militar cheio de glórias, mas contrata junto a um condottiere o aluguel de mercenários para lutarem as suas guerras.

3) O rei, vestido numa luxuosa indumentária totalmente inadequada para lutar na guerra, consulta os seus generais e ministros da guerra, que têm seus postos numa estrutura complexa, dominada por civis.

4) O rei (que pode estar disfarçado de presidente ou primeiro-ministro) vestindo uma roupa de trabalho e negociando com o seu pessoal e com representantes devidamente constituídos dos principais interesses civis e da população em geral (Tilly, 1996, p. 290). 
O chefe desvinculou-se de uma indumentária marcial, indicando que a ética da valentia perdeu sua força evocativa nas sociedades modernas. Contudo, as vestes discretas e a aparência inofensiva dos líderes políticos modernos não devem iludir sobre a força de seu poder coercitivo. Qualquer presidente francês concentra em suas mãos um poder de coerção infinitamente superior ao de um Luís XIV, embora nenhum deles, pelo menos em público, vanglorie-se disso.

A violência concentrada no topo pelo Estado provocou a pacificação da base. Essa fórmula antiga, remontando à definição weberiana do Estado como monopolizador da violência legítima, é bastante pertinente para caracterizar a sociedade moderna. Nesse ambiente, as oportunidades para a manifestação da ética aristocrática da coragem e a destreza na utilização da violência física são altamente restringidas. Restou aos valentes ingressarem nas forças armadas ou policiais ou adentrarem o universo do crime, burlando as restrições sociais. Na vida cotidiana, a manifestação considerada legítima da valentia é restrita a poucas situações, como a reação a um assalto, a demonstração de heroísmo numa situação de catástrofe, ou enfrentamento da força policial em protestos sociais populares.

\section{A definição sociológica de valentia}

Este artigo valeu-se da sociologia compreensiva de Weber e Simmel para conceituar a valentia. Para Weber, as motivações valorativas dos indivíduos são de fundamental importância para se compreender a ação social, uma vez que os seres humanos agem no mundo influenciados por sistemas simbólicos. Como a realidade social é complexa, a busca pelo sentido dá-se por meio de escolhas motivadas por valores culturais. O indivíduo transita por diferentes esferas valorativas, mas só uma delas expressa as suas verdadeiras convicções sobre o mundo. A complexidade 
da vida e da personalidade induz um passeio por várias esferas, mas cada um, no seu íntimo, escolhe a mais coerente com os seus pressupostos morais, éticos e filosóficos.

Na competição das esferas, religião é proeminente, pois oferece a valiosa "cura da alma": a possibilidade de salvar a alma ou manipular o sobrenatural por meio da magia para melhorar a vida neste mundo. A esfera econômica é regulada pelo dinheiro e busca apenas o lucro, pouco se importando com pressupostos éticos ou religiosos. A esfera política é regulada pelo "pragmatismo das razões de Estado" (Weber, 1982a, p.383), inclusive utilizando a violência em guerras e conflitos internos, o que conflita fortemente com muitas das outras esferas. A esfera estética busca o belo e, por isso, o artista "sacrifica" a sua vida à arte. A esfera erótica, uma das mais irracionais, "oferece o auge insuperável da realização do desejo de amor na fusão direta das almas entre si" (Weber, 1982a, p. 397). E, por fim, a esfera intelectual atrai aqueles que buscam a racionalidade científica ou pretendem dedicar-se à "ciência como vocação".

Antes do processo de racionalização, as diferentes esferas estavam de certa forma subordinadas à da religião. Por isso, a religião poderia criticar e até limitar os excessos das outras: a usura da economia, o pragmatismo amoral da política, a iconofilia da estética, a luxúria do erotismo e o ateísmo do intelectualismo. Com o desencantamento do mundo, ocorrido com a modernidade, a religião perdeu a sua proeminência de arbitragem ética, ocorrendo o que Weber denomina de "politeísmo dos valores". Em um mundo desencantado, o indivíduo não precisa esconder ou disfarçar as suas preferências valorativas. Cada um justifica suas escoIhas a partir da ética da convicção, que

apresenta-se como uma ética absoluta, na qual todos os valores são subordinados a um deles que, dessa maneira, se transforma em um valor absoluto, em um exemplo de conduta a ser imitado por quem atua conforme tal ética. (Saint-Pierre, 1999, p. 148). 
A ética da convicção é absoluta porque o integrante de cada esfera está convicto da pertinência dos valores últimos que regem a sua vida, julgando os seus atos apenas a partir deles. Weber utiliza, como exemplo, a orientação de "oferecer a outra face" ao agressor, totalmente racional para o cristão, mas completamente irracional para o guerreiro. É que ambos olham essa atitude de ângulos diferentes: do horizonte ético no qual suas vidas se situam.

Essas reflexões de Weber configuram uma importante chave teórica para a análise de uma esfera valorativa que foi apenas aludida em seus escritos: a esfera da valentia. Ao abordar as aptidões das diferentes classes e estamentos para determinado tipo de ética religiosa, Weber ressaltou que

O modo de viver do guerreiro não tem afinidade nem com a ideia de uma providência bondosa nem com a de exigências éticas sistemáticas de um deus supramundano. Conceitos como "pecado", "redenção", "humildade" religiosa não apenas costumam estar muito distantes do sentimento de dignidade de todas as camadas politicamente dominantes, sobretudo da nobreza, como diretamente o ofendem. [...] Enfrentar a morte e as irracionalidades do destino humano com coragem é para o guerreiro uma coisa cotidiana, e os riscos e aventuras deste mundo ocupam tanto espaço em sua vida que não exige nem aceita de bom grado de qualquer religião outra coisa que não a proteção contra feitiçarias e ritos cerimoniais, adequados ao sentimento de dignidade estamental, que se tornam componentes da convenção estamental, e, quando muito, ainda preces sacerdotais pela vitória ou por uma morte feliz, que conduza ao céu dos heróis. (Weber, 1994, p. 323).

Weber refere-se ao indivíduo que guia a sua vivência pelo princípio ético da valentia. Um guerreiro ideal não aceita os princípios de humildade de determinadas éticas religiosas, de igualitarismo democrático de determinas correntes políticas, de sentimentalismo do erotismo. Essa caracterização weberiana, ainda que rudimentar, dos valores que 
regem a personalidade do guerreiro possibilita um ponto de partida para se construir um tipo ideal da valentia, a partir de exemplos empíricos da realidade histórica.

O principal aspecto numa ética da valentia é aquele já evidenciado por Weber: "enfrentar a morte e as irracionalidades do destino humano com coragem". A princípio, o valente não deseja a morte, pelo menos não do mesmo modo que os românticos desiludidos - o infeliz e lacrimoso personagem de Goethe, Werther, parecer-Ihe-ia uma pessoa desprovida de valor. $\mathrm{O}$ valente não quer morrer, mas não recua diante do perigo. A honra, a glória e a emoção da vitória valem o risco. Nesse sentido, o paradigma da valentia é exemplificado por Aquiles, que escolheu a morte gloriosa a uma vida longa e medíocre ${ }^{3}$. Também é exemplificado pela vigorosa atitude dos 300 espartanos em frente ao poderoso exército persa em Termópilas, que, ao serem informados de que o número de flechas a ser atiradas pelos persas era tão grande que iria obscurecer o sol, um deles, chamado Dieneces, respondeu à provocação, afirmando que, ao menos, lutariam na sombra (Heródoto, livro 7, cap. 76). Ciente de que seguiriam brevemente para o Hades, o espartano ainda foi capaz de troçar os inimigos.

Enfrentar com sobriedade o risco da morte, por si só, não basta para caracterizar a valentia. Os mártires cristãos, por exemplo, não temiam a morte e alguns até agradeciam seus algozes por libertarem-nos das agruras deste mundo (Cesaréia, 2000, p. 202). Porém, faltava-lhes um outro componente essencial da ética da valentia: a capacidade de matar alguém. De certo modo, aquele que vislumbra a própria morte tem mais condições de

\footnotetext{
${ }^{3}$ De acordo com Assunção (2003, p. 101), Aquiles mudou de posição após a morte. Quando se encontrou com Ulisses, no Hades, demonstrou arrependimento pela sua morte precoce: "Não me consoles da morte, ilustre Ulisses! Preferiria, sendo um lavrador, alugar meus serviços a um outro, a um homem sem-lote, que não tem muitos recursos, do que reinar entre todos os mortos já perecidos". Aquiles admitiu que a prudência de Ulisses foi mais vantajosa do que o impulso heroico que o vitimou.
} 
vislumbrar a morte do outro. Aquele que tem pouco apreço por sua a vida a ponto de colocá-la na loteria do destino não terá, consequentemente, muito apreço pela vida alheia. O valente, portanto, é o indivíduo disposto a morrer, mas sobretudo, disposto a matar.

No entanto, poucas pessoas têm a especialização psicológica necessária para matar alguém. Até entre os ferozes predadores, o ato de matar outro da mesma espécie é um recurso extremo: as piranhas brigam entre si utilizando a cauda e não as suas mortíferas presas. Com exceção dos sociopatas, a capacidade de matar não parecer ser algo natural, mas, sim, uma das inúmeras habilidades apreendidas socialmente. A repugnância em matar o inimigo ficou evidenciada, durante a II Guerra Mundial, quando pesquisadores do Exército americano descobriram que apenas 20\% dos soldados conseguiram apertar o gatilho, mesmo estando o inimigo na mira (Grossman, 1996). A partir desses dados, o Exército mudou o treinamento militar, fazendo um condicionamento psicológico em direção à brutalização e à insensibilização. $\mathrm{O}$ resultado foi um aumento espantoso nos índices dos dispostos a matar: 55\% na Guerra da Coreia e 90\% na Guerra do Vietnã.

A evolução tecnológica dos armamentos facilitou o ato de matar. $\mathrm{O}$ historiador Eric Hobsbawm (1995, p. 57) percebeu que a "tecnologia tornava suas vítimas invisíveis, como não podiam fazer as pessoas evisceradas por baionetas ou vistas pela mira das armas de fogo". Inegavelmente, apertar um botão desencadeando um ataque aéreo é muito mais confortável para a psique de um ser humano normal do que apertar o gatilho de um fuzil. Porém, mesmo o fato de a mira do fuzil permitir ver o adversário, ele é ainda uma arma mais impessoal do que as armas brancas. Nesse sentido, as impressionantes 960 mortes em batalha atribuídas a um certo Artur, o provável homem real por trás do mito, aliado dos bretões contra os saxões (Le Goff, 2011, p. 30), foram mais difíceis do que as 705 atribu- 
ídas ao franco-atirador finlandês Simo Hayha, durante a sua participação na "Guerra de Inverno" (1939) (Farey; Spicer, 2009, p. 117).

A evolução tecnológica dos armamentos mudou o perfil dos guerreiros. Após a I Guerra Mundial, o modelo valorizado de soldado foi o franco-atirador, o sniper, capaz de abater o inimigo a uma longa distância, numa caçada solitária e silenciosa. Com isso, homens franzinos bons de mira destacaram-se nas batalhas. Não só homens, mas até mulheres, como a bela soldado soviética Lyudmila Pavlichenko, especialista em tiros a mais de 500 metros, que matou mais de 300 alemães durante a II Guerra (Silva, 2011).

A proeminência dos franco-atiradores nas guerras modernas possibilita uma discussão sobre honra, coragem e valentia ${ }^{4}$ que remonta a Grécia Antiga. A ética militar grega clássica preconizava que o "arco não era a prova de valentia de um homem", pois o ideal de guerreiro era o hoplita que, com suas longas lanças erguidas, corre em direção ao inimigo até o choque avassalador. $\mathrm{O}$ uso do arco e flecha era destinado ao efebo, que se valia da emboscada e não do enfrentamento cara a cara (Vidal-Naquet, 1999, p. 126 e 134). O arco seria a arma preferida dos covardes: foi uma flecha atirada pelo medroso Páris que matou o grande Aquiles. Flávio Josefo relata que, durante o cerco de Jerusalém, o pequenino Jônatas

\footnotetext{
${ }^{4}$ Essas três categorias estão entrelaçadas, mas possuem aspectos distintos. Para Elias (1997, p. 96), o conceito de honra possui significados diferenciados nas sociedades aristocráticas e nas sociedades burguesas: nas primeiras, a honra era equiparada à coragem na utilização da violência; já nas segundas, honra equivaleria à honorabilidade, no sentido de moral e honesto. $\mathrm{A}$ categoria "coragem" também admite uma disposição para praticar a violência (como a coragem do guerreiro) ou a disposição para fazer o que é certo moralmente (como a coragem do pacifista). Nesse sentido, a categoria "valentia", desconsiderando os seus usos metafóricos, emergiu em sociedades aristocráticas, onde era considerada como a síntese de honra e coragem. Elias (1997, p. 115) afirma ainda que a sistematização do conceito aristocrático de honra e coragem no mundo moderno foi efetivada pioneiramente por Maquiavel e depois, com maior amplitude, na filosofia de Nietzsche, na qual o "seu cântico de louvor à guerra e à força" expressou a adoção pela burguesia de "um código guerreiro que tinha primeiramente pertencido à nobreza".
} 
desafiava insolentemente os soldados romanos para um duelo, até que o vigoroso cavaleiro Pudente se dispôs a enfrentá-lo. Durante o combate, o romano escorregou e foi morto pelo judeu, que lhe pisou o corpo e insultou os romanos. Um legionário, inflamado pela indignação, atravessou o corpo do valente Jônatas com uma flechada, o que causou extrema indignação entre os judeus (Josefo, 2004, p. 1356). Quando da repressão à Coluna Prestes pela Força Pública de São Paulo, foi utilizado um avião, o Sikorsky S-31 para localizar e bombardear os revolucionários. O avião caiu sem completar seu objetivo, no dia 10 de outubro de 1926, em território goiano, e trouxe satisfação àqueles que viam como uma indisfarçada covardia bombardear soldados pelo alto (Oliveira, 2011, p. 108). Esses exemplos indicam que, na lógica de guerra tradicional, o tipo mais honroso de luta era aquele travado face a face com o inimigo, em igualdade de condições.

Com a evolução tecnológica dos armamentos, evidentemente, o combate em campo aberto tornou-se inviável. A metralhadora, o fuzil, o tanque e o avião tornaram-se legítimos na arte da guerra. Com isso, as ações dos snipers e dos pilotos de avião legitimaram-se como ato de bravura. O sargento Adelbert F. Waldron III foi distinguido pela segunda mais importante honraria militar norte-americana, Distinguished Service Crosses, por matar mais 109 vietnamitas, sendo que um deles foi a uma distância maior de 900 metros $^{5}$. Pelo lado dos soviéticos, o destaque é o soldado Vasily Saytsev, que se destacou na terrível Batalha de Stalingrado, matando, no mínimo, 149 alemães com sua incrível pontaria, tornando-se um herói nacional soviético.

Apesar do reconhecimento da ação dos snipers e pilotos de avião na guerra moderna, o tipo mais alto de valentia ainda continua sendo o

\footnotetext{
${ }^{5} \mathrm{~A}$ ação de Waldron foi ainda mais impressionante pelo fato de ele estar numa plataforma em movimento. In. http://www.history.army.mil/books/Vietnam/Sharpen/ch06.htm. Acesso em: 28 maio 2013.
} 
duelo face a face. Essa constatação não deriva duma visão aristocrática de mundo, nostálgica dos duelos coletivos ou individuais da nobreza guerreira. A valorização do duelo como o exemplo maior de valentia tem sua justificativa na sociologia de Georg Simmel, mais precisamente na sua reflexão sobre a aventura.

A rotina social é dominada pelo mundo do trabalho, em que se busca paz, estabilidade e segurança pessoal e econômica. Já o mundo da aventura é marcado pela busca da glória pessoal, pela audácia e pela coragem (Holanda, 1999, p. 44). Para Simmel, a aventura opõe-se aos interesses prosaicos da vida e, por isso, os típicos aventureiros são o artista, o jogador e os sedutores. Nos três casos, a rotina da vida é preterida diante da experiência estética, da imprevisibilidade da vitória ou da derrota ou da intensidade do relacionamento erótico. Simmel define aventura como uma ação que "extrapola o contexto da vida", ou seja, aquilo que está desconectado da rotina cotidiana.

Contudo o mais alto grau de aventureiro é o valente. Ninguém meIhor do que ele é capaz de "um completo abandonar-se às forças e às chances do mundo, que tanto podem nos favorecer como nos destruir" (Simmel, 2005, p. 175). O valente é o maior dos jogadores, pois aposta a sua própria vida nos jogos de guerra ou nos duelos privados. O valente não apenas se opõe à rotina da vida, como também faz o artista e o sedutor, mas desafia a própria noção de vida ao flertar perigosamente com a morte. Nesse sentido, ele é o verdadeiro "aventureiro profissional [que] faz da ausência de sistema da sua vida um sistema de vida" (Simmel, 2005, p. 173). Da mesma forma como o jogador que, pelo fato de não enxergar nenhum sentido na vida, cria um sentido irracional por meio da superstição a fim de driblar a aleatoriedade das forças do destino, o valente, como bem observou Weber, também é inclinado à busca de "proteção contra feitiçarias e ritos cerimoniais" para livrar-se da morte ou, ao menos, ter uma morte feliz. 
Se "o aventureiro é também o exemplo mais forte do homem a-histórico, do ser presente" (Simmel, 2005, p. 172), o valente é novamente o aventureiro típico. Adentrar o universo da valentia requer estar sempre aberto à possibilidade de abandonar o passado - a família, o emprego, os amigos - e não se preocupar com o futuro. Requer ser capaz de optar pelo risco da morte heroica em detrimento da velhice longa e corriqueira. Requer apostar "na chance flutuante, no destino e no que é impreciso" (Simmel, 2005, p. 176).

É indubitável que o valente não arrisca a vida despreparado. Ele, assim como o aventureiro, "confia, de algum modo, em sua própria força. Antes de tudo, porém, confia em sua própria sorte; no fundo, ele se fia em uma singular união não diferenciada entre ambos" (Simmel, 2005, p. 176). O risco é fundamental para a definição da aventura, pois em situações em que se tem a certeza da vitória, não se configura um jogo, pois está ausente o acaso. O verdadeiro duelo mortal é aquele em que um dos dois adversários pode perder ou ganhar.

Confiar a própria existência à irracionalidade do destino ou à habilidade física é o ápice da coragem. De todas as formas de aventura que a vida oferece, nenhuma é mais intensa do que a luta entre dois homens em igualdade de condições. Um dos pontos mais altos de Um certo Capitão Rodrigo foi a descrição do duelo entre o valente Capitão Rodrigo Cambará e o filho do coronel:

Juvenal Terra transmitia instruções. Bento sairia pela direita e Rodrigo pela esquerda, a galope, para se encontrarem atrás do cemitério. Não haveria testemunhas, pois existia no país uma lei contra duelos. Os adversários deviam apear, arregaçar as mangas e brigar. O que escapasse, viria depois até a praça dar o sinal para irem buscar o corpo do outro (Veríssimo, 2000, p. 49).

O que era para ser uma disputa justa, utilizando apenas os punhos e a faca, termina em um ato covarde de Bento, que se valeu da arma de 
fogo para atingir Cambará. O texto de Veríssimo é um exemplo da ignomínia quase universal da traição às regras dos duelos. A linha tênue que separa os heróis dos vilões é justamente a obediência ou não às regras aristocráticas do combate justo.

Poucos homens atingiram o ideal pleno da valentia como o herói japonês Miyamoto Musashi (1584-1645). Desde criança, iniciou os pesados treinamentos típicos dos samurais na técnica do Kendô, a arte de lutar com espadas. Musashi atingiu a excelência, inclusive inovando ao usar duas espadas em combate. Aos 13 anos, enfrentou o seu primeiro adversário em um duelo, matando o já experiente Arima Kihei a golpes de bastão. Ele próprio relata que "depois disso corri de província em província duelando com estrategistas de várias escolas, e nunca deixei de vencer, embora contasse mais de sessenta encontros. Isso ocorreu entre as idades de treze e vinte e oito ou vinte e nove anos" (Musashi, 1998, p. 13). O seu mais importante duelo foi a vitória sobre o samurai Sasaki Kojiro, o que fez dele o maior guerreiro do Japão de seu tempo.

Musashi devotou-se à valentia, isolando-se em treinamento constante para aperfeiçoar a sua arte de matar. A sua vida foi uma grande aventura, na qual matar e morrer era apenas um jogo: "O caminho do guerreiro é a aceitação resoluta da morte" (Musashi, 1998, p. 14). Resumiu os pontos principais da sua filosofia de vida em 21 máximas, conhecidas como o "Caminho da Autoconfiança" ou "Dokkõdõ" (Musashi, [1645]). Nelas, nota-se um mergulho pleno na esfera da valentia ("nunca, nem por um momento sequer, meu coração e minha alma desviaram-se do caminho da espada") e o conflito com as outras esferas valorativas: com a economia ("Sou inteiramente livre de ganância em toda minha vida"), com a religião ("Eu adoro deuses e budas, mas nunca penso em depender deles"), com o amor erótico ("Eu nunca sonho em apaixonar-me por uma mulher"), com o hedonismo ("Eu nunca desejo um alimento saboroso"). O ascetismo de rejeição ao mundo de Musashi rivaliza-se em 
igualdade de condições com os monges religiosos. A diferença é que o seu deus era a espada ("Eu não tenho apreço por nenhum objeto, exceto espadas e outras armas").

Musashi é o exemplo pleno da ética da valentia, pois adestrou o seu corpo para o combate, não temeu a morte, não hesitou em matar, fez proezas admiráveis, e não demonstrou compaixão nem ódio pelos adversários. Nas pacificadas sociedades ocidentais, em que o duelo mortal foi proibido pelo Estado, o que mais se aproxima do ideal do guerreiro japonês é o lutador de artes marciais. Ele também faz da valentia a sua profissão e estilo de vida e assume os riscos - embora raramente fatais - do seu sucesso e fracasso. O lutador é uma figura admirada desde a antiguidade. Os campeões olímpicos da Grécia Antiga conquistavam, além da fama, várias regalias: não pagar pelas refeições, sentar-se na primeira fila nos anfiteatros, construir a própria estátua em Olímpia, além de um elevado prêmio em dinheiro (Swaddling, 1999, p. 90-95). O maior pugilista da antiguidade foi Milo de Crotona, que foi campeão em cinco olimpíadas entre 532 a 516 a. C., até ser derrotado pelo jovem Timotheos, em 512 a. C., quando já contava 40 anos de idade. O maior pugilista da era moderna, Muhammad Ali, foi campeão mundial dos pesos pesados por três vezes, protagonizando, com Georg Foreman, a mais famosa luta de boxe do século XX. Venceu 56 lutas e perdeu cinco. As duas personalidades demonstram que, apesar do preparo, da experiência, da abnegação - Ali suportou 12 rounds contra Ken Norton com o maxilar quebrado - os campeões, como todos os jogadores, também perdem ${ }^{6}$.

\footnotetext{
${ }^{6}$ É preciso considerar que havia diferenças fundamentais entre os lutadores da Antiguidade e os modernos, no tocante às regras e à tolerância com a violência. De acordo com Elias e Dunning (1992, p. 202), na Antiguidade, em competições como o Pancrácio, "a luta durava até que um dos oponentes desistisse. As regras eram tradicionais, não escritas, indiferenciadas e na sua aplicação eram, por certo, flexíveis. Parece que, tradicionalmente, morder e arrancar os olhos era proibido. Mas antes que o juiz pudesse afastar um agressor dominado pela fúria do combate, quando este era afastado do seu oponente, o dano já estava consumado".
} 
É também uma especificidade da ética da valentia na pacificada sociedade ocidental a valorização do sacrifício individual em prol do grupo. O sacrifício pelo grupo é consequência da disciplina do exército, que estimula uma solidariedade entre os soldados, ao criar, com o recrutamento, uma comunidade comunista de guerreiros, separada totalmente do exterior (Weber, 1982b, p. 296). É inevitável que homens solteiros, convivendo por longos anos e passando pelas mesmas privações, criem laços de solidariedade difíceis de serem quebrados. O soldado "é membro de uma sociedade com uma grande coesão e que é de molde a substituir, em parte, a família" (Durkheim, 2003, p.243). Essa coesão explicaria, segundo o sociólogo francês, a maior propensão dos militares, principalmente os de elite, ao suicídio altruísta.

Há vários exemplos dessa abnegação de soldados. Durante o cerco de Jerusalém, um soldado sírio a serviço dos romanos, chamado Sabino, atendeu ao apelo do comandante Tito para assaltar um trecho da muralha defendido pelos judeus. Sabino pagou com a vida a ousadia da empreitada (Josefo, 2004, p. 1344). No exército norte-americano, a mais alta comenda militar, a seletiva Medal of Honor, é concedida principalmente para os casos de sacrifício do indivíduo a favor do grupo. Na Guerra do Iraque, em 14 de abril de 2004, o cabo Jason Dunham, ao ser atacado por uma granada, cobriu-a com o seu capacete e corpo, arcando com o ônus da explosão, salvando a vida de, ao menos, dois soldados (Dunham, J. Iraq War). Esse exemplo, dentre as centenas de outros existentes entre os agraciados com a Medal of Honor, demonstra o quanto essas atitudes de abnegação são valorizadas entre os militares.

Porém, o sacrifício individual dos terroristas modernos em prol do grupo não se configura um ato de valentia. Falta-lhe as regras que regulamentam a violência, explícitas - no caso dos duelos - e implícitas - no caso das guerras. O terrorista suicida tem coragem de morrer e matar, mas 
a sua ação é um jogo em que só ele conhece as regras. Foi por isso que "o velho revolucionário Friedrich Engels ficou horrorizado com a explosão de uma bomba republicana irlandesa em Westminster Hall - porque, como velho soldado, afirmava que a guerra se travava contra combatentes e não contra não-combatentes" (Hobsbawm, 1995, p. 22). Desse modo, o tipo mais elevado de valentia requer não só a coragem e a habilidade de matar, mas fazê-lo dentro das regras consideradas justas. Assim, os homens-bombas e os terroristas, de modo geral, não são valentes. Podem até ser admirados em seu grupo por sua abnegação à causa, mas eles próprios justificam a violência atípica a partir de sua fraqueza diante do poderio inimigo.

A verdadeira valentia requer um ato heroico que demonstre coragem e técnica em uma situação desvantajosa. O valente é aquele capaz de uma ação grandiosa que lhe tornaria famoso em sua época e nas vindouras. Hannah Arendt (1997, p. 77) conceituou essa noção de grandeza que legitimava a valentia na Antiguidade grega: "grande era o que mereceria a imortalidade, o que devia ser admitido na companhia das coisas que perduram para sempre, envolvendo a futilidade dos mortais com sua majestade insuperável". No entanto, essa busca desenfreada por reconhecimento desestrutura as relações econômicas e jurídicas de qualquer sociedade. Por isso, ela é típica de lugares em que o Estado está fragilizado, como o feudalismo europeu e japonês ou as zonas de fronteira, como o velho oeste norte-americano. Na própria Grécia, como em Roma, em períodos mais clássicos, a busca pela bravura individual foi desestimulada diante da disciplina coletiva na falange e na legião.

Apesar disso, a valentia ainda está associada à ação grandiosa e extraordinária. A própria Medal of Honor, conferida pelo presidente dos Estados Unidos, destaca a "bravura acima e além do dever" do combatente. Nesse sentido heroico, um exemplo é o do tenente texano Audie Murphy, 
que representou as forças norte-americanas na II Guerra Mundial. Ao ter a sua companhia, composta por apenas 20 homens, cercada por tropas alemãs numericamente bem superiores, Murphy, em vez de recuar, subiu em um tanque em chamas e atirou freneticamente nos inimigos durante uma hora, mesmo tendo sido ferido na perna. Ele conseguiu atingir cerca de 50 inimigos, garantiu a manutenção da posição ocupada e salvou a vida de seus comandados. Por sua bravura, Murphy tornou-se o soldado mais condecorado da Segunda Guerra (Murphy, A. World War II) ${ }^{7}$.

O banco de dados do Exército Norte-Americano referente aos agraciados pela Medal of Honor está cheio de atos heroicos, desde a resistência à dor, como foi o caso de Richard O’Neill que, na I Guerra, foi ferido por vários tiros, mas continuou impassivelmente lutando contra os inimigos alemães (O'Neill, I World War $)^{8}$, até ações de incrível ousadia, como foi o caso do tenente Patrick Regan que, desarmado e ferido, tomou de assalto uma posição defendida por uma metralhadora, capturando 30 soldados inimigos (Regan, I World War) ${ }^{9}$.

\section{Conclusão}

Foi preciso uma pequena dose de valentia para escrever este artigo. Os riscos da empreitada são muitos e foi preciso uma certa ousadia teórica para, dentro de uma abordagem culturalista, tentar definir um ethos da valentia. Nesse sentido, este texto pode ser útil nas reflexões sobre a

\footnotetext{
${ }^{7}$ Medal of Honor Recipient (M-S) - World War II . Murphy, Audie L. In. http://www.history. army.mil/html/moh/wwll-m-s.html. Acessado em 11 jun. 2013.

${ }^{8}$ Medal of Honor Recipient (M-S) - World War I. O’ Neill, Richard W. In. http://www.history. army.mil/html/moh/worldwari.html. Acessado em 11 jun. 2003.

${ }^{9}$ Medal of Honor Recipient (M-S) - World War I . Regan,Patrick. In. http://www.history.army. mil/html/moh/worldwari.html. Acessado em 11 jun. 2003
} 
violência, pois mostra que existe um viés que confere positividade e legitimidade a determinadas ações violentas, ungidas sob o manto da valentia.

Esse ethos da valentia requer um estilo de vida e convicções morais que destoam da maioria absoluta dos seres humanos. Ele requer um desprendimento quase religioso das coisas do mundo, ao optar-se por enfrentar o perigo da morte. E mais difícil do que isso: requer uma disposição psicológica para não hesitar em matar ou ferir o adversário, se necessário for. Além disso, requer, muitas vezes, uma disciplina corporal e psicológica para adestrar o corpo e a personalidade para enfrentar e vencer os desafios e ser reconhecido como um herói em sua comunidade. A valentia exige que a vida seja vivida como uma aventura, voltada para o presente, sem se importar com as experiências do passado ou com as expectativas de futuro. Carlos Castañeda, apesar de ter uma definição de valentia bem mais ampla do que a deste artigo, resumiu bem o dilema do guerreiro:

Somente a ideia de morte torna o guerreiro suficientemente desprendido para ser capaz de se entregar a qualquer coisa. Ele sabe que a morte o espreita e não lhe dará tempo de se agarrar a nada, de modo que ele experimenta, sem ansiedade, tudo de todas as coisas (Castañeda, 1971, p. 27).

Evidentemente, as recomendações weberianas sobre o caráter abstrato e metodológico do tipo ideal devem ser levadas em conta na análise da valentia. Por conflitar fortemente com as atividades cotidianas, a valentia costuma se manifestar apenas esporadicamente em situações bem específicas. Poucos seres humanos devotaram-se intensamente à valentia, no sentido existencial que foi levado a cabo pelo samurai japonês Miyamoto Musashi. A maioria dos seres humanos reserva a sua valentia para ocasiões mais específicas, como é o caso das guerras, das brigas particulares, dos torneios de lutas, nos esportes de aventura ou nas caçadas.

A modernidade, com a emergência e intensificação do processo civilizador, restringiu a valentia. Em uma situação de paz, os valentes são 
um estorvo e um perigo para a estabilidade social. Por isso, eles têm o seu espaço de atuação restringido a determinadas atuações: soldado, policial, segurança particular, lutador profissional, criminoso, etc. Mesmo, assim, com a exceção óbvia dos criminosos, todas as outras atividades submeteram-se a rígidas regras para inibir o uso indiscriminado da violência. Apesar disso, a valentia ainda é um ideal valorativo poderoso no mundo moderno. Os livros antigos que expressam um ideal aristocrático da valentia, como o famoso Arte da guerra de Sun Tzu, são cada vez mais vendidos e utilizados como metáfora da competição no mundo do trabalho. As academias de artes marciais estão cheias de homens e muIheres buscando aprimorar a técnicas de luta e defesa pessoal. A valentia é predominante no universo da ficção destinada ao consumo de massa. Essa é a grande ambiguidade da nossa época: a valentia é cada vez mais cultivada, mas cada vez mais perde espaço na prática social. A frase atribuída a Goethe demonstra o modo ambíguo como a valentia é concebida em nossa época: "a multidão não pode ficar sem homens valentes, e os valentes são sempre um peso para ela" .

Eliézer Cardoso de Oliveira é Doutor em Sociologia pela UnB. Professor do curso de História e do Mestrado em Território e Expressões Culturais no Cerrado, da UEG, em Anápolis - GO.\ ezi@uol.com.br

\section{Referências}

1. ARENDT, H. Entre o passado e o futuro. Trad. de Mauro W. B. Almeida. São Paulo: Editora Perspectiva, 1997.

2. ASSUNÇÃO, T. R. Ulisses e Aquiles repensando a Morte (Odisséia XI, 478491). Kriterion, Belo Horizonte, no 107, Jun/2003, p.100-109. Disponível em: http://www.scielo.br/pdf/kr/v44n107/v44n107a08.pdf. Acesso em 5 jun. 2013.

3. CASTAÑEDA, C. Uma estranha realidade. Trad. de Luzia M. Costa. Rio de Janeiro: Record, 1971. 
4. CESARÉIA, E. de. História Eclesiástica. Trad. Monjas beneditinas do Mosteiro de Maria Mãe de Cristo. São Paulo: Paulus, 2000.

5. DURKHEIM, É. O suicídio. Trad. de: Alex Marins. São Paulo: Martin Claret, 2003.

6. ELIAS, N. A solidão dos moribundos. Rio de Janeiro: Jorge Zahar Editor, 2001 a.

7. ELIAS, N. A sociedade da Corte: investigação sobre a sociologia da realeza e da aristocracia de corte. Tradução de Pedro Süssekind. Rio de Janeiro: Jorge Zahar Ed. 2001 b.

8. ELIAS, N. Os alemães: a luta pelo poder e a evolução do habitus nos séculos XIX e XX. Tradução de Álvaro Cabral. Rio de Janeiro: Zahar, 1997.

9. ELIAS, N. O processo civilizador: Vol. 1- uma história dos costumes. Rio de Janeiro: Jorge Zahar Editor, 1994.

10. ELIAS, N. Processo Civilizador. Vol. 2 - Formação do Estado e Civilização. Trad. Ruy Jungmann. Rio de Janeiro: Jorge Zahar Editor, 1993.

11. ELIAS, N.; DUNNING, E. A busca da Excitação: desporto e lazer no processo civilizacional. Tradução de Maria Manuela Almeida e Silva. Lisboa: Difel, 1992.

12. FAREY, P.; SPICER, M. Sniping: an Illustrated History. Minneapolis, EUA: MBI Publishing Company, 2009.

13. GROSSMAN, D. On Killing: the psychological cost of learning to kill in war and society. New York: Litle Brown and Co., 1996.

14. HERÓDOTO. História. Trad. J. Brito Broca. Rio de Janeiro: V. M. Jackson editores, 1964.

15. HOBSBAWM, E. Era dos Extremos: o breve século XX (1914 - 1991). Trad. Marcos Santarrita. São Paulo: Cia das Letras, 1995.

16. HOLANDA, S. B. de. Raízes do Brasil. São Paulo: Cia das Letras, 1999.

17. JOSEFO, F. Obra completa. História dos Hebreus. Trad. Vicente Pedroso. RJ: Casa Publicadora das Assembléias de Deus, 2004.

18. LE GOFF, J. Heróis e maravilhas da Idade Média. Trad. de: Stephania Matousek. Petrópolis, RJ: Vozes, 2011.

19. MUSASHI, M. O livro dos cinco anéis. Trad. Fernando B. Ximenes. Rio de Janeiro: Ediouro, 1988.

20. MUSASHI, M. Dokkõdõ. 1645. In: https://pt.wikipedia.org/wiki/ Dokk\%C5\%8Dd\%C5\%8D Acessado em 18 ago. 2016. 
21. OLIVEIRA, E. C. O lado oculto da lua: perigos e riscos da modernização. SERPA, Élio C. et. al. Narrativas da modernidade: história, memória e literatura. Uberlândia, MG: Eduf, 2011. P. 93-116.

22. SAINT-PIERRE, H. L. Max Weber: entre a paixão e a razão. Campinas, SP: Editora da Unicamp, 1999.

23. SILVA, H.R. Snipers: os atiradores de Elite. 20 de Junho de 2011. In. http:// www.planobrazil.com/snipers-os-atiradores-de-elite-ii/. Acessado em 20 jun. 2013.

24. SIMMEL, G. A aventura. In: SOUZA, J.; ÖELZE, B. (org.). Simmel e a modernidade. Brasília: Ed. da UnB, 2005. P. 169-184.

25. SWADDLING, J. The Ancient Olympic Games de Judith Swaddling. Austin, Texas: University of Texas Press, 1999.

26. TILLY, C. Coerção, Capital e Estados europeus. Trad. Geraldo Souza. São Paulo: Edusp, 1996.

27. VERÍSSIMO, É. Um certo Capitão Rodrigo. SP: Globo, 2000.

28. VIDAL-NAQUET, P. O Filoctetes de Sófocles e a Efebia. Trad. de Maria Cavalcante. In. VERNANT, J.-P.; VIDAL-NAQUET, P. Mito e Tragédia na Grécia Antiga. São Paulo: Editora Perspectiva, 1999. P. 125-145.

29. WEBER, M. As rejeições religiosas do mundo e suas direções. In. GERTH, H. H.; MILLS, C. W. (org.) Max Weber - Ensaios de Sociologia. Trad. de Waltensir Dutra. Rio de Janeiro: Editora Guanabara Koogan, 1982a. P. 371-410.

30. WEBER, M. O significado da disciplina. In: GERTH, H. H.; MILLS, C. W. (org.) Max Weber - Ensaios de Sociologia. Trad. de Waltensir Dutra. Rio de Janeiro: Editora Guanabara Koogan, 1982b. p. 292-305.

31. WEBER, M. Economia e Sociedade. Vol 1. Trad. de Regis Barbosa e Karen Elsabe Barbosa. Brasília: Editora da UnB, 1994.

Recebido em: 10.06.2015

Aceite Final: 05.08.2015 